\title{
DNA Interaction Studies of a Cobalt(II) Mixed-Ligand Complex Containing Two Intercalating Ligands: 4,7-Dimethyl-1, 10-Phenanthroline and Dipyrido $\left[3,2-a: 2^{\prime}, 3^{\prime}-c\right]$ phenazine
}

\author{
Nahid Shahabadi and Maryam Mahdavi \\ Department of Chemistry, Faculty of Science, Razi University, Kermanshah 74155, Iran \\ Correspondence should be addressed to Nahid Shahabadi; nahidshahabadi@yahoo.com
}

Received 15 November 2012; Accepted 5 December 2012

Academic Editors: B. F. Ali, V. Barba, A. M. Fonseca, and L. G. Lopes

Copyright (C) 2013 N. Shahabadi and M. Mahdavi. This is an open access article distributed under the Creative Commons Attribution License, which permits unrestricted use, distribution, and reproduction in any medium, provided the original work is properly cited.

\begin{abstract}
A new cobalt(II) complex $\left[\mathrm{Co}(\mathrm{dppz})_{2}(4,7-\mathrm{dmp})\right]^{2+}(4,7-\mathrm{dmp}=4,7$-dimethyl-1,10-phenanthrolline $)$ and dppz $=$ dipyrido[3,2- $a: 2^{\prime}-$ $3^{\prime}-c$ phenazine has been synthesized and characterized by elemental analysis (CHN), FT-IR, and UV-visible (UV-Vis) spectroscopic techniques. The DNA-binding property of the complex has been investigated employing absorption spectroscopy, fluorescence spectroscopy, circular dichroism, and viscosity measurements. The experimental results show that the complex can bind to DNA in an intercalation mode. In comparison with previous study, the DNA-binding affinity of $\left[\mathrm{Co}(\mathrm{dppz})_{2}(4,7-\mathrm{dmp})\right]^{2+}\left(K_{b}=1.1 \cdot 10^{6}\right.$ $\left.\mathrm{M}^{-1}\right)$ is smaller than that of complex $\left[\mathrm{Co}(\mathrm{dppz})_{2}(2,9-\mathrm{dmp})\right]^{2+}\left(K_{b}=2.5 \cdot 10^{6} \mathrm{M}^{-1}\right)$.
\end{abstract}

\section{Introduction}

Cobalt was accepted as an essential metal element widely distributed in the biological systems such as cells and body, and thus the interaction of DNA with cobalt complex has attracted much attention [1]. The biological role of cobalt is mainly focused on its presence in the active center of vitamin B12, which regulates indirectly the synthesis of DNA. Additionally, cobalt is involved in the coenzyme of vitamin B12 used as a supplement of the vitamin [2], and at least eight cobalt-dependent proteins have been reported [3]. Since the first reported studies into the biological activity of cobalt complexes [4], diverse structurally characterized cobalt complexes showing antitumor antiproliferative $[5,6]$, antimicrobial $[7,8]$, antifungal $[9,10]$, antiviral $[11,12]$, and antioxidant [13] activities have been reported.

Deoxyribonucleic acid (DNA) plays a significant role in the life process because it carries the inheritance information and leads the biological synthesis of proteins and enzymes through the replication and transcription of genetic information in living cells. DNA is especially a good target for metal complexes as it gives a wide variety of potential metal binding sites [14-16]. For example, the rich DNA electron bases and phosphate groups are suitable for direct covalent coordination at the metal centre. There are noncovalent binding behaviors such as hydrogen bonding and electrostatic binding in the grooved regions of the DNA, along with the intercalation of planar aromatic ligands in the stacked base pairs [17-23]. The interaction of DNA with transition metal complexes has gotten intensive attention in the last few years in order to develop new novel nonradioactive probes of DNA structure $[24,25]$, new therapeutic agents that cleave DNA [26-28] and DNA-mediated electron transfer reactions [29].

Recently, binding of metal complexes with 1,10phenanthroline or modified phenanthroline moieties to DNA has attracted much attention [30-32]. Synthesis of new cobalt(II) complexes enabled chemists to extensively study the ability of these complexes to act as probes in investigating the structure of DNA, when these metal complexes are incorporated with either 1,10-phenanthroline or a modified phenanthroline moiety as one of the ligands. Among such metal complexes of intercalatable ligands, those incorporating dipyrido[3,2-a:29,39-c]phenazine (dppz) are known to possess unique characteristics. 
Taking into consideration the biological role and activity of cobalt and its complexes containing intercalating ligands, we have initiated the investigation of the interaction of cobalt(II) with two phenanthroline and one dppz as ligands [33]. In this context, we report the synthesis, characterization, and DNA-binding studies of a new cobalt(II) complex containing two dppz and 4,7-dimethyl phenanthroline ligands to find the effect of methyl substituent and different kinds of ligands on the mode of DNA binding.

\section{Experimental}

2.1. Materials. O-phenylenediamine and 4,7-dimethyl-1,10phenanthroline were purchased from Merck. Doubly distilled deionized water was used throughout. Highly polymerized calf thymus DNA (CT-DNA) and Tris-HCl buffer were purchased from Sigma Co. Solutions of DNA in $5 \mathrm{mM}$ Tris- $\mathrm{HCl}, 50 \mathrm{mM} \mathrm{NaCl}$ buffer $(\mathrm{pH} 7.2$ ) gave a ratio of $\mathrm{UV}$ absorbance at 260 and $280 \mathrm{~nm}$ of $1.8-1.9: 1$, indicating that the DNA was sufficiently free of protein. The concentration of calf thymus DNA was determined spectrophotometrically using the molar absorptivity $6600^{-1} \mathrm{~cm}^{-1}$ at $260 \mathrm{~nm}$. The stock solutions were stored at $4^{\circ} \mathrm{C}$ and used over no more than 4 days.

2.2. Synthesis of $\left[\mathrm{Co}(d p p z)_{2}(4,7-d m p)\right] \mathrm{Cl}_{2} \quad$ Complex. The metal complex $\left[\mathrm{Co}(\mathrm{dppz})_{2} \mathrm{Cl}_{2}\right]$, where dppz $=$ dipyrido-[3,2$\left.a: 2^{\prime}, 3^{\prime}-c\right]$ phenazine was prepared by a slight modification of the reported procedure [34]. Methanolic solutions of dppz ligands (2.823 g; $10 \mathrm{mM}$ ) were refluxed for $1 \mathrm{~h}$. To this, anhydrous cobalt chloride $(0.65 \mathrm{~g} ; 5 \mathrm{mM})$ in hot methanol $(10 \mathrm{~mL})$ was added. The solution was filtered and the precipitate was washed with methanol and diethyl ether, and dried under vacuum.

$\left[\mathrm{Co}(\mathrm{dppz})_{2} \mathrm{Cl}_{2}\right](3.125 \mathrm{~g} ; 5 \mathrm{mM})$ was dissolved in watermethanol $(20 \mathrm{~mL}, 1: 2 \mathrm{~V} / \mathrm{V})$, then, $4,7-\mathrm{dmp}(1.04 \mathrm{~g} ; 5 \mathrm{mM})$ was added. The solution was stirred under reflux. After $3 \mathrm{~h}$, the reaction mixture was cooled at room temperature and filtered. The precipitate was washed with ice water and methanol.

Analytical data (\%) for $\left[\mathrm{Co}(\mathrm{dppz})_{2}(4,7-\mathrm{dmp})\right] \mathrm{Cl}_{2} \cdot 4 \mathrm{H}_{2} \mathrm{O}$, found (calculated); C, 62.5 (61.5); H, 4.0 (3.89); N, 14.21 (14.35). IR data $\left(\mathrm{cm}^{-1}\right)$ : 1541 (ring), 1515 (C=C), 1429 (CCH), 840 (Phen), 729 (Phen), 1342 (Me), 412 (Co-N); molar conductance, $\left(\Omega^{-1} \mathrm{~cm}^{2} \mathrm{~mol}^{-1}\right)$ in DMF: $142(1: 2 \mathrm{elec}-$ trolyte).

2.3. Instrumentation. The elemental analysis was performed using a Heraeus CHN elemental analyzer. The molar conductance of the complex was measured in DMF at room temperature on an ELICO (CM 82T) conductivity bridge. IR spectra were obtained with an ABB BOMEM MB 104 FTIR spectrometer using $\mathrm{KBr}$ discs for $500-4000 \mathrm{~cm}^{-1}$ range.

Absorbance spectra were recorded using an HP spectrophotometer (Agilent 8453) equipped with a thermostated bath (Huber polysat cc1). Absorption titration experiments were conducted by keeping the concentration of complex constant $\left(5 \times 10^{-5} \mathrm{M}\right)$ while varying the DNA concentration.

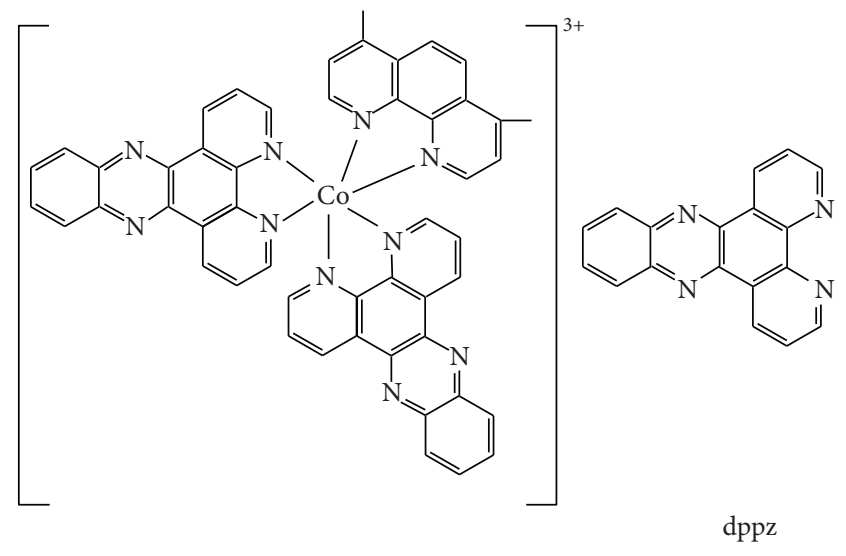

FIgURE 1: Structures of the dppz ligand and its Co(II) complex.

Absorbance values were recorded after each successive addition of DNA solution, followed by an equilibration period.

All fluorescence measurements were carried out with a JASCO spectrofluorometer (FP6200) by keeping the concentration of complex constant while varying the DNA concentration at three different temperatures $(279,293$, and $310 \mathrm{~K})$.

CD measurements were recorded on a JASCO (J-810) spectropolarimeter by keeping the concentration of DNA constant $\left(5 \times 10^{-5} \mathrm{M}\right)$ while varying the complex concentration.

Viscosity measurements were made using a viscosimeter (SCHOT AVS 450) that was maintained at $25 \pm 0.5^{\circ} \mathrm{C}$ using a constant temperature bath. The DNA concentration was fixed at $5 \times 10^{-5} \mathrm{M}$ and flow time was measured with a digital stopwatch. The mean values of three replicated measurements were used to evaluate the viscosity $\eta$ of the samples. The values for relative specific viscosity $\left(\eta / \eta_{0}\right)^{1 / 3}$, where $\eta_{0}$ and $\eta$ are the specific viscosity contributions of DNA in the absence $\left(\eta_{0}\right)$ and in the presence of the $\mathrm{Co}(\mathrm{II})$ complex $(\eta)$, were plotted against $1 / R$.

\section{Results and Discussion}

3.1. Synthesis and Characterization. Transition metal complexes of dppz have been found to exhibit interesting photophysical properties due to the multiple excited states available: $3 \pi-\pi^{*}$ (phenazine), $3 \pi-\pi^{*}$ (phen), or 3MLCT. Dppz is soluble in ethanol. It is worth to note that the UV-Vis spectrum of the ligand shows characteristic peaks at 249 and $265 \mathrm{~nm}$, a shoulder at $290 \mathrm{~nm}$, and a multiple in the range $325-400 \mathrm{~nm}$, the latter interpreted as a $\pi-\pi^{*}$ transition. The electronic absorption spectrum of $\left[\mathrm{Co}(4,7-\mathrm{dmp})(\mathrm{dppz})_{2}\right]^{2+}$ (Figure 1) is well characterized by two intense ligand centered transitions in the UV regional. The bands at 325-400 $\mathrm{nm}$ are characteristic of the interligand (IL) $\pi-\pi^{*}$ transition of the dppz ligand. The low-energy bands at $427 \mathrm{~nm}$ are assigned as Co $(\mathrm{d} \pi) \mathrm{dppz}\left(\pi^{*}\right)$ metal-to-ligand charge transfer (MLCT) transition. The IR spectrum of the complex shows band in the $412 \mathrm{~cm}^{-1}$ ascribable to the Co-N stretching. Molar conductance $\left(\Omega^{-1} \mathrm{~cm}^{2} \mathrm{~mol}^{-1}\right)$ in DMF shows $1: 2$ electrolyte. 
3.2. Electronic Absorption Titration. The application of electronic absorption spectroscopy in DNA-binding studies is one of the most useful techniques. A complex bound to DNA through intercalation usually results in hypochromism and red shift (bathochromism), due to the intercalation mode involving a strong stacking interaction between aromatic chromophore and the base pairs of DNA. The extent of the hypochromism in the visible MLCT band is commonly consistent with the strength of intercalative interaction [35]. The UV-V is absorption spectrum of $\mathrm{Co}(\mathrm{dppz})_{2}(\mathrm{dmp})^{2+}$ in aqueous buffer solution (Figure 2) displays a broad MLCT band at $425 \mathrm{~nm}$ and intense intraligand $\pi \rightarrow \pi^{*}$ absorptions characteristic of the dppz chromophore [36] below $400 \mathrm{~nm}$ region. In the presence of increasing concentrations of calf thymus DNA, a marked hypochromism in the dppz $\pi \rightarrow$ $\pi^{*}$ and MLCT transitions is apparent, accompanied by an isosbestic point at $461 \mathrm{~nm}$ (Figure 2). The spectral characteristics obviously suggest that the $\mathrm{Co}$ (II) complex interact with DNA most likely through a mode that involves a stacking interaction between the aromatic chromophore and the base pairs of DNA. In order to compare the DNA-binding affinities of the complex quantitatively, the intrinsic binding constant, $K_{b}$, to DNA was obtained by monitoring the changes of the MLCT absorbance at $424 \mathrm{~nm}$ according to the following equation [37]:

$$
\begin{aligned}
\frac{\varepsilon_{a}-\varepsilon_{f}}{\varepsilon_{b}-\varepsilon_{f}} & =\frac{b-\left(b^{2}-2 K_{b}^{2} C_{t}[\mathrm{DNA}] / s\right)^{1 / 2}}{2 K_{b} C_{t}}, \\
b & =1+K_{b} C_{t}+\frac{K_{b}[\mathrm{DNA}]}{2 s},
\end{aligned}
$$

where [DNA] is the concentration of DNA in nucleotides, $\varepsilon_{a}$ is the extinction coefficient $(\mathrm{A} /[\mathrm{M}])$ observed for the MLCT absorption band at a given DNA concentration, and $\varepsilon_{f}$ and $\varepsilon_{b}$ are the extinction coefficient for the free $\mathrm{Co}(\mathrm{II})$ complex and the extinction coefficient for the Co(II) complex in the fully bounded form, respectively. $K_{b}$ is the equilibrium binding constant in $\mathrm{M}^{-1}, C_{t}$ is the total $\mathrm{Co}$ (II) complex concentration, and $s$ is the binding site size. The intrinsic binding constant of the complex was measured to be $(1.1 \pm 0.3) \times 10^{6} \mathrm{M}^{-1}(s=$ $1.97 \pm 0.09$ ) (Table 1 ). The $K_{b}$ value of the complex is relatively close to that of the classical intercalator EB [38]. The $K_{b}$ value is in the same order of those of bidentate $\left[\mathrm{Ru}(\mathrm{L})_{2}(\mathrm{dppz})\right]^{2+}$ complexes $[39,40]\left(>10^{6}\right)$, where $\mathrm{L}=\mathrm{bpy}$, phen, dmb, and dmp. The large hypochromism and $K_{b}$ value observed in the electronic absorption titration experiment for the complex, suggest that the titled complex most likely intercalatively bind to DNA, involving a strong stacking interaction between the aromatic chromophore (dppz) and the base pairs of the DNA.

3.3. Viscosity Measurements. The DNA-binding mode of the complex was further investigated by viscosity measurements. Hydrodynamic measurements (e.g., viscosity, sedimentation), which are sensitive to the increase in length of DNA, are regarded as the least ambiguous and the most critical tests of a binding mode in solution in the absence of crystallographic structure data. A classical intercalation leads to the DNA helix to lengthen because the base pairs of DNA are separated

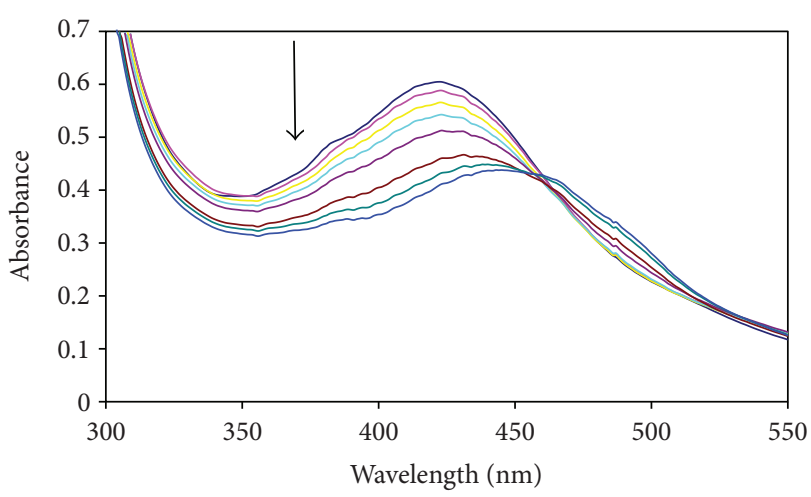

FIgURE 2: Absorption spectra of the complex in $10 \mathrm{mM}$ Tris buffer at $\mathrm{pH} 7.2$, upon addition of CT-DNA. $([\mathrm{Co}]=50 \mu \mathrm{M},[\mathrm{DNA}]=$ $0-300 \mu \mathrm{M})$. Arrow shows the absorbance changing upon increasing of DNA concentrations.

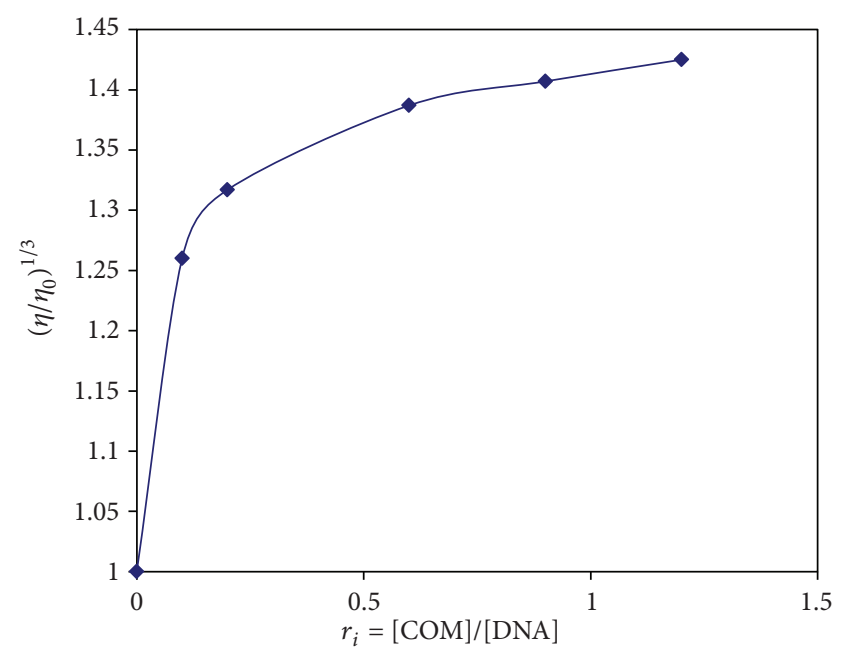

FIGURE 3: Effect of increasing amounts of $\left[\mathrm{Co}(\mathrm{dppz})_{2}(4,7-\mathrm{dmp})\right]^{2+}$ on the viscosity of CT-DNA $\left(5 \times 10^{-5} \mathrm{M}\right)$ in $10 \mathrm{mM}$ Tris-HCl buffer $\left(r_{i}=0.1,0.2,0.4,0.8\right.$, and 1.2$)$.

to accommodate the bound ligand, and thus result in the increase of DNA viscosity.

In contrast, a partial or nonclassical intercalation of a ligand could bend (or kink) the DNA helix and thus reduce its effective length and, concomitantly, its viscosity. The effect of the complex on the viscosity of DNA in comparison with previous results in our laboratory is shown in Figure 3. In the presence of the complex, the viscosity of DNA is increased which is similar to the behavior of well-known DNAintercalator $\left(\left[\mathrm{Ru}(\mathrm{bpy})_{2}(\mathrm{dppz})\right]^{2+}\right)$ [41]. The experimental results further support that the complex binds to DNA in an intercalation mode.

3.4. Fluorescence Studies. The emission intensity of the complex from its MLCT excited states upon excitation at $454 \mathrm{~nm}$ is found to depend on DNA concentration. Figure 4 shows the emission spectrum of the complex in the presence of varying amounts of DNA. As seen from the figure, the intensity of emission at $559 \mathrm{~nm}$ decreases appreciably in the presence 
TABLE 1: Absorption spectra $\left(\lambda_{\max } / \mathrm{nm}\right)$ and DNA-binding constants, $K_{b}$, of the titled complex in comparison with the previous results.

\begin{tabular}{|c|c|c|c|c|c|}
\hline Complex & $\lambda_{\max }($ free $)$ & $\lambda_{\max }($ bound) & $\Delta \lambda(\mathrm{nm})$ & $H(\%)$ & $K_{b}\left(\mathrm{M}^{-1}\right)$ \\
\hline$\left[\mathrm{Co}(\mathrm{dppz})_{2}\left(2,9-\mathrm{Me}_{2}\right.\right.$ phen $\left.)\right]$ & 422 & 458 & 36 & 22.5 & $4.63 \times 10^{6}$ \\
\hline$\left[\mathrm{Co}(\mathrm{dppz})_{2}\left(4,7-\mathrm{Me}_{2}\right.\right.$ phen $\left.)\right]$ & 422 & 460 & 38 & 27.7 & $2.36 \times 10^{6}$ \\
\hline
\end{tabular}

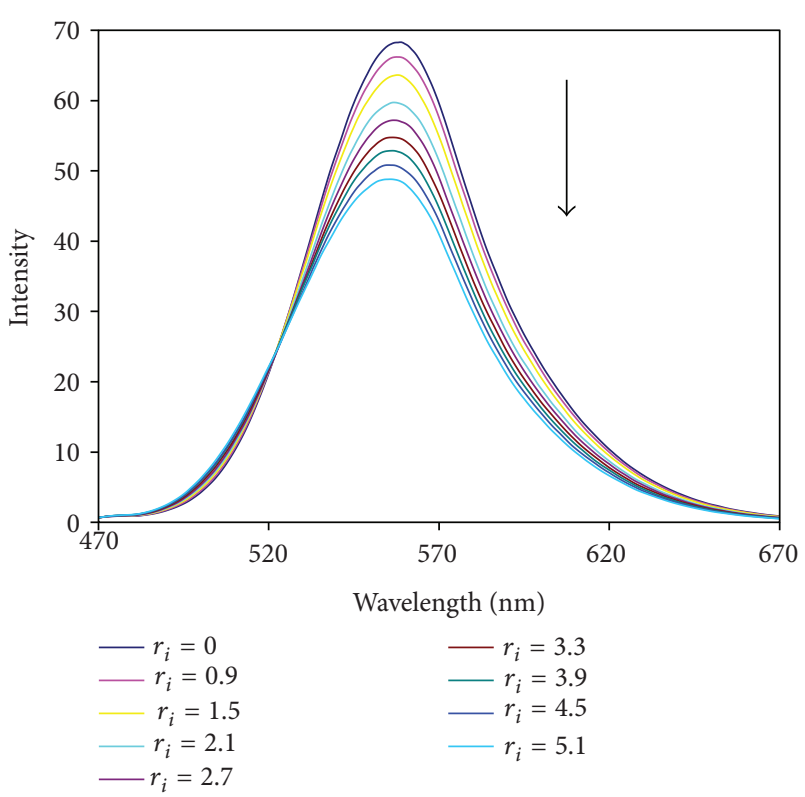

FIGURE 4: Emission spectra of the complex in Tris- $\mathrm{HCl}$ buffer in the absence and presence of CT-DNA. Arrow shows the intensity change upon increasing DNA concentrations. [Co] $=20 \mu \mathrm{M}$.

of DNA. Fluorescence quenching may result from a variety of processes such as excited state reactions, energy transfer, ground-state complex formation, and collisional processes. Collisional or dynamic quenching refers to a process where the fluorophore and the quencher come into contact during the lifetime of the excited state, whereas static quenching refers to a fluorophore-quencher complex formation. SternVolmer constant, $K_{\mathrm{SV}}$, is used to evaluate the fluorescence quenching efficiency. According to the classical Stern-Volmer equation:

$$
\frac{F_{0}}{F}=1+K_{q} \tau_{0}[\mathrm{D}]=1+K_{\mathrm{SV}}[\mathrm{D}],
$$

where $F_{0}$ and $F$ stand for the fluorescence intensities in the absence and presence of quencher, and [D] is the quencher concentration. $K_{\mathrm{SV}}$ is the Stern-Volmer quenching constant, which substitutes $K_{q}$ as $K_{\mathrm{SV}}=K_{q} \tau_{0}$, where $K_{q}$ is the bimolecular quenching constant and $\tau_{0}$ is the lifetime of the fluorophore in the absence of quencher. The results in Table 2 indicate that the probable quenching mechanism of this complex by CT-DNA involves dynamic quenching because $K_{\mathrm{SV}}$ increases with increasing temperature [42].

3.5. Binding Constants and Binding Sites. Fluorescence titration data were used to determine the binding constant $\left(K_{f}\right)$ and binding stoichiometry $(n)$ for the complex formed between the cobalt complex and CT-DNA. Figure 4 shows the fluorescence spectra of the complex in the presence of different concentrations of CT-DNA. The data show that the fluorescence intensity at $559 \mathrm{~nm}$ decreases in the presence of CT-DNA. This change in fluorescence intensity at $454 \mathrm{~nm}$ was used to estimate $K_{f}$ and $n$ for the binding of complex to CTDNA from the following equation [43]:

$$
\log \frac{\left(F_{0}-F\right)}{F}=\log K_{f}+n \log [\mathrm{DNA}] .
$$

Based on the equation, the binding constant $K_{f}$ and the number of binding sites are obtained and shown in Table 3 .

3.6. Thermodynamic Parameters and the Nature of the Binding Forces. According to the thermodynamic data, interpreted as follows, the model of interaction between a drug and biomolecule can be (1) $\Delta H<0$ and $\Delta S<0$, hydrophobic forces; (2) $\Delta H>0$ and $\Delta S>0$, van der Waals interactions and hydrogen bonds; (3) $\Delta H>0$ and $\Delta S<0$, electrostatic interactions [44]. In order to elucidate the interaction of our complex with DNA, the thermodynamic parameters were calculated. Thermodynamic parameters are calculated based on the temperature dependence of the average affinity constant for complex binding at 279, 293, and $310 \mathrm{~K}$. The values of $\Delta H_{0}$ and $\Delta S_{0}$ are obtained from the slope and intercept of linear Van't Hoff plot and are presented in Table $4:$

$$
\ln K=-\frac{\Delta H_{0}}{R T}+\frac{\Delta S_{0}}{R},
$$

where $K$ is the binding constant at absolute temperature $T$ and $R$ is gas constant. The free energy change $\Delta G_{0}$ is calculated from the following equation:

$$
\Delta G_{0}=\Delta H_{0}-T \Delta S_{0} .
$$

When we apply this analysis to the binding of the complex with CT-DNA, we find that $\Delta H<0$ and $\Delta S<0$. Therefore, hydrophobic forces are probably the main forces in the binding of the investigated complex to CT-DNA. It was found that the intercalation of the complex is stabilized by hydrophobic interactions and van der Waals forces [45].

3.7. Circular Dichroic Spectral Studies. To establish in more detail whether binding of the complex brings about any significant conformational change of the DNA double helix, circular dichroism (CD) spectra of CT-DNA were recorded at increasing complex/CT-DNA ratios. The observed CD spectrum of natural calf thymus DNA consists of a positive band at $275 \mathrm{~nm}$ due to base stacking and a negative band at $245 \mathrm{~nm}$ due to helicity, which is characteristic of DNA in right-handed B form (Figure 5) [46]. 
TABLE 2: Dynamic enhancement and bimolecular enhancement constants for interactions between Co(II) complex and CT-DNA at different temperatures.

\begin{tabular}{lccc}
\hline Temperature $(\mathrm{K})$ & Linear equation & $K_{\text {SV }}$ & $K_{q}$ \\
\hline 279 & $Y=0.986+1339 X$ & 1339 & $1.34 \times 10^{11}$ \\
293 & $Y=0.987+1540 X$ & 1540 & $1.54 \times 10^{11}$ \\
310 & $Y=0.997+1702 X$ & 1702 & $1.7 \times 10^{11}$ \\
\hline
\end{tabular}

TABLE 3: Linear equations of $\log \left(F-F_{0}\right) / F$ versus $\log [\mathrm{DNA}]$ and $K_{f}$ of $\mathrm{Co}(\mathrm{II})$ complex with DNA at different temperatures.

\begin{tabular}{lccc}
\hline Temperature $(\mathrm{K})$ & Linear equation & $R^{2}$ & $K_{f}$ \\
\hline 279 & $Y=1.35 X+4.52$ & 0.993 & $3.3 \times 10^{4}$ \\
293 & $Y=1.22 X+4.03$ & 0.99 & $1.07 \times 10^{4}$ \\
310 & $Y=0.948 X+2.99$ & 0.991 & $0.97 \times 10^{3}$ \\
\hline
\end{tabular}

TABLE 4: Thermodynamic parameters and binding constants for the binding of Co(II) complex to CT-DNA.

\begin{tabular}{lcccc}
\hline$T(\mathrm{~K})$ & $\log K\left(\mathrm{M}^{-1}\right)$ & $\Delta G_{0}\left(\mathrm{~kJ} \mathrm{~mol}^{-1}\right)$ & $\Delta H_{0}\left(\mathrm{~kJ} \mathrm{~mol}^{-1}\right)$ & $\Delta S_{0}\left(\mathrm{~J} \mathrm{~mol}^{-1} \mathrm{~K}^{-1}\right)$ \\
\hline 279 & 4.52 & -24.6 & -81.704 & -204.66 \\
293 & 4.03 & -21.73 & -81.704 & -204.66 \\
310 & 2.99 & -18.26 & -81.704 & -204.66 \\
\hline
\end{tabular}

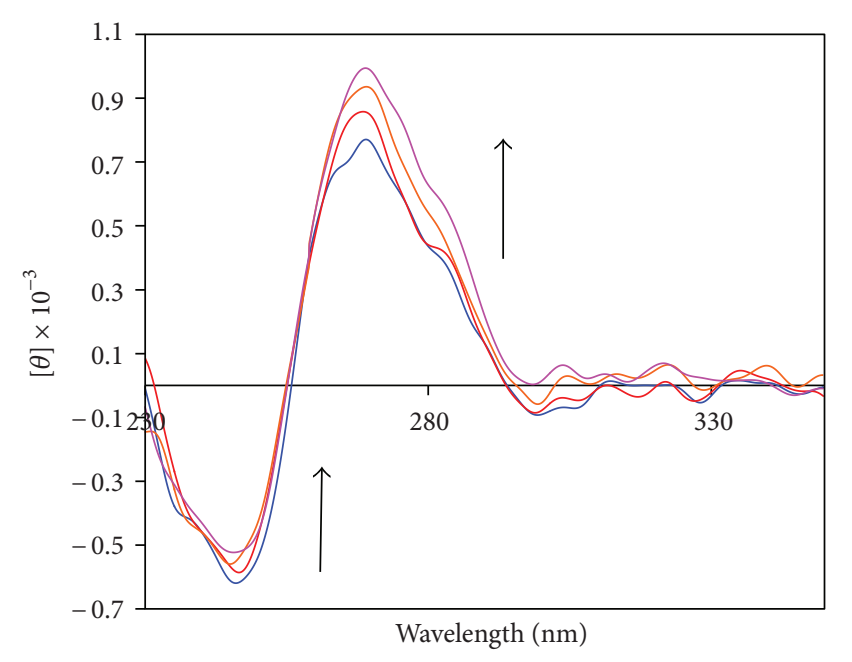

$$
\begin{array}{ll}
- \text { DNA } & -4 \\
-0.2 & 0.6
\end{array}
$$

FIGURE 5: Circular dichroic spectra of calf thymus DNA $(5.0 \times$ $\left.10^{-5} \mathrm{M}\right)$ in $5 \mathrm{mM}$ Tris- $\mathrm{HCl} / 50 \mathrm{mM} \mathrm{NaCl}(\mathrm{pH} 7.2)$ in the presence of increasing amounts of Complex. $\left(r_{i}=[\mathrm{Co}] /[\mathrm{DNA}]=0.0,0.2,0.4\right.$, and 0.6).

When the present complex is incubated with CT DNA at the $1 / R(=[$ complex]/[DNA] $)$ value the CD spectrum of DNA undergoes changes in both positive and negative bands (Figure 5). The complex shows decrease and increase in intensities of the negative and positive bands, respectively and suggesting slight changes in DNA helicity upon interaction with the complex. Such spectral changes are characteristic of $B$ to $A$ conformational change. Similar observations have been made for $\left[\mathrm{Co}(\text { bipy })_{2} \text { (ip) }\right]^{3+}$ and certain $\mathrm{Ru}(\mathrm{II})$ complexes bound to CT DNA $[47,48]$.

\section{Conclusion}

A novel $\mathrm{Co}(\mathrm{II})$ complex $\left[\mathrm{Co}(4,7-\mathrm{dmp})(\mathrm{dppz})_{2}\right] \mathrm{Cl}_{2}$ has been synthesized and characterized. The experimental results indicate that the complex binds to DNA via an intercalative mode of binding. Probably the most striking result emerging from this study is a quantitative evaluation of the contribution phenazine moieties to the DNA binding affinity. By comparison with previous study [49], an additional binding affinity is gained upon substitution of dmp ligand for dppz. It was found that the present complex $\left(K_{b}=2.5 \pm 0.4 \times\right.$ $10^{6} \mathrm{M}^{-1}$ ) binds to DNA 10 order of magnitude higher than the $\left[\mathrm{Co}(\mathrm{dppz})(2,9-\mathrm{dmp})_{2}\right] \mathrm{Cl}_{2}$ complex $\left(K_{b}=3.6 \pm 0.2 \times\right.$ $10^{5} \mathrm{M}^{-1}$ ) [49]. Such a change in the binding affinity is readily understood because the dppz ligand of the Co(II) complex interacts with double helical ct-DNA by classical intercalation similar to that established for ethidium or daunomycin. The results of this study clarify and quantify the contribution of specific substituent to the stabilization of the DNA binding and may provide a basic guidance for further design of new DNA-binding agents of metal complexes. Furthermore, in comparison with previous study in our laboratory, the DNA-binding affinity of $\left[\mathrm{Co}(\mathrm{dppz})_{2}(4,7-\mathrm{dmp})\right]^{2+}$ is smaller than that of complex $\left[\mathrm{Co}(\mathrm{dppz})_{2}(2,9-\mathrm{dmp})\right]^{2+}\left(K_{b}=2.5 \times\right.$ $\left.10^{6} \mathrm{M}^{-1}\right)$.

\section{Acknowledgment}

Financial support from Razi University Research Center is gratefully acknowledged. 


\section{References}

[1] H. Shimakoshi, T. Kaieda, T. Matsuo, H. Sato, and Y. Hisaeda, "Syntheses of new water-soluble dicobalt complexes having two cobalt-carbon bonds and their ability for DNA cleavage," Tetrahedron Letters, vol. 44, no. 28, pp. 5197-5199, 2003.

[2] P. J. Sadler, "Inorganic chemistry and drug design," Advances in Inorganic Chemistry, vol. 36, pp. 1-48, 1991.

[3] P. V. Bernhardt and G. A. Lawrance, "Cobalt," in Comprehensive Coordination Chemistry II, J. A. McCleverty and T. J. Meyer, Eds., vol. 6, chapter 1, pp. 1-45, 2003.

[4] M. D. Hall, T. W. Failes, N. Yamamoto, and T. W. Hambley, "Bioreductive activation and drug chaperoning in cobalt pharmaceuticals," Dalton Transactions, no. 36, pp. 3983-3990, 2007.

[5] H. López-Sandoval, M. E. Londoño-Lemos, R. Garza-Velasco et al., "Synthesis, structure and biological activities of cobalt(II) and zinc(II) coordination compounds with 2-benzimidazole derivatives," Journal of Inorganic Biochemistry, vol. 102, no. 56, pp. 1267-1276, 2008.

[6] I. Ott, A. Abraham, P. Schumacher et al., "Synergistic and additive antiproliferative effects on human leukemia cell lines induced by combining acetylenehexacarbonyldicobalt complexes with the tyrosine kinase inhibitor imatinib," Journal of Inorganic Biochemistry, vol. 100, no. 11, pp. 1903-1906, 2006.

[7] D. U. Miodragovic, G. A. Bogdanovic, Z. M. Miodragovic et al., "Interesting coordination abilities of antiulcer drug famotidine and antimicrobial activity of drug and its cobalt(III) complex," Journal of Inorganic Biochemistry, vol. 100, no. 9, pp. 1568-1574, 2006.

[8] K. Nomiya, A. Yoshizawa, K. Tsukagoshi, N. C. Kasuga, S. Hirakawa, and J. Watanabe, "Synthesis and structural characterization of silver(I), aluminium(III) and cobalt(II) complexes with 4-isopropyltropolone (hinokitiol) showing noteworthy biological activities. Action of silver(I)-oxygen bonding complexes on the antimicrobial activities," Journal of Inorganic Biochemistry, vol. 98, no. 1, pp. 46-60, 2004.

[9] J. Lv, T. Liu, S. Cai, X. Wang, L. Liu, and Y. Wang, "Synthesis, structure and biological activity of cobalt(II) and copper(II) complexes of valine-derived schiff bases," Journal of Inorganic Biochemistry, vol. 100, no. 11, pp. 1888-1896, 2006.

[10] Z. Weiqun, Y. Wen, X. Liqun, and C. Xianchen, "N-Benzoyl$\mathrm{N}^{\prime}$-dialkylthiourea derivatives and their Co(III) complexes: structure, and antifungal," Journal of Inorganic Biochemistry, vol. 99, no. 6, pp. 1314-1319, 2005.

[11] A. Bottcher, T. Takeuchi, K. I. Hardcastle, T. J. Meade, and H. B. Gray, "Spectroscopy and electrochemistry of Cobalt(III) Schiff base complexes," Inorganic Chemistry, vol. 36, pp. 2498-2504, 1997.

[12] T. Takeuchi, A. Bottcher, C. M. Quezada, T. J. Meade, and H. B. Gray, "Inhibition of thermolysin and human alpha-thrombin by cobalt(III) Schiff base complexes," Bioorganic \& Medicinal Chemistry, vol. 7, pp. 815-819, 1999.

[13] F. Dimiza, A. N. Papadopoulos, V. Tangoulis et al., "Biological evaluation of non-steroidal anti-inflammatory drugs-cobalt(II) complexes," Dalton Transactions, vol. 39, pp. 4517-4528, 2010.

[14] A. Sitlani, E. C. Long, A. M. Pyle, and J. K. Barton, "DNA photocleavage by phenanthrenequinone diimine complexes of rhodium(III): shape-selective recognition and reaction," Journal of the American Chemical Society, vol. 114, no. 7, pp. 2303-2312, 1992.
[15] L. Jin and P. Yang, "Effect of polyamine-induced compaction and aggregation of DNA on the formation of radiationinduced," Polyhedron, vol. 16, pp. 3395-3403, 1997.

[16] Y.-M. Song, X.-1. Lu, M.-1. Yang, and X.-R. Zheng, "Precursors for mitochondrial DNA replication," Transition Metal Chemistry, vol. 30, pp. 499-513, 2005.

[17] Q.-L. Zhang, J.-G. Liu, H. Chao, G.-Q. Xue, and L.-N. Ji, “DNAbinding and photocleavage studies of cobalt(III) polypyridyl complexex," Journal of Inorganic Biochemistry, vol. 83, pp. 49-55, 2001.

[18] Q.-L. Zhang, J.-G. Liu, H. Xu et al., "Synthesis, characterization and DNA-binding studies of cobalt(III) polypyridyl complexes," Polyhedron, vol. 20, no. 26-27, pp. 3049-3055, 2001.

[19] C.-W. Jiang, H. Chao, H. Li, and L.-N. Ji, "Synthesis, characterization and DNA-binding studies of ruthenium(II) terpyridine complexes," Journal of Inorganic Biochemistry, vol. 93, pp. 247-255, 2003.

[20] V. G. Vaidyanathan and B. U. Nair, "Synthesis, characterization and electrochemical studies of mixed ligand complexes of ruthenium(II) with DNA," Dalton Transactions, no. 17, pp. 2842-2848, 2005.

[21] H. Chao, W.-J. Mei, Q.-W. Huang, and L.-N. Ji, “DNA binding studies of ruthenium(II) complexes containing asymmetric tridentate ligands," Journal of Inorganic Biochemistry, vol. 92, no. 3-4, pp. 165-170, 2002.

[22] K. Jiao, X.-W. Qing, W. Sun, and F. J. Fang, "Synthesis, characterization and DNA-binding properties of a new cobalt(II) complex: $\mathrm{Co}(\mathrm{bbt})_{2} \mathrm{Cl}_{2}$," Journal of Inorganic Biochemistry, vol. 99, no. 6, pp. 1369-1375, 2005.

[23] R. S. Kumar and S. Arunachalam, "Synthesis, characterization and DNA binding studies of a polymer-cobalt(III) complex containing the $2,2^{\prime}$-bipyridyl ligand," Polyhedron, vol. 25 , no. 16 , pp. 3113-3117, 2006.

[24] X.-L. Wang, H. Chao, H. Li et al., "DNA interactions of cobalt(III) mixed-polypyridyl complexes containing asymmetric ligands," Journal of Inorganic Biochemistry, vol. 98, no. 6, pp. 1143-1150, 2004.

[25] K. E. Erkkila, D. T. Odom, and J. K. Barton, "Recognition and reaction of metallointercalators with DNA," Chemical Reviews, vol. 99, no. 9, pp. 2777-2795, 1999.

[26] V. W.-W. Yam, K. K.-W. Lo, K.-K. Cheung, and R. Y.-C. Kong, “Dipyrido[3, 2-a:2',3'-c]phenazine-Tethered Oligo-DNA: synthesis and Deoxyribonucleic acid binding and photocleavage studies of rhenium(I) dipyridophenazine complexes," Journal of the Chemical Society, Dalton Transactions, pp. 2067-2081, 1997.

[27] J. Ren and J. B. Chaires, "Sequence and structural selectivity of nucleic acid binding ligands," Biochemistry, vol. 38, no. 49, pp. 16067-16075, 1999.

[28] J. K. Barton and A. L. Raphael, "Photoactivated stereospecific cleavage of double-helical DNA by cobalt(III) complexes," Journal of the American Chemical Society, vol. 106, no. 8, pp. 2466-2468, 1984.

[29] J. K. Barton and A. L. Raphael, "Site-specific cleavage of lefthanded DNA in pBR322 by LCo(DIP) 3 3+," Proceedings of the National Academy of Sciences of the United States of America, vol. 82, no. 19, pp. 6460-6464, 1985.

[30] X. L. Wang, H. Chao, H. Li et al., "DNA interactions of cobalt(III) mixed-polypyridyl complexes containing asymmetric ligands," Journal of Inorganic Biochemistry, vol. 98, no. 6, pp. 1143-1150, 2004. 
[31] S. Srinivasan, J. Annaraj, and P. R. Athappan, "Spectral and redox studies on mixed ligand complexes of cobalt(III) phenanthroline/bipyridyl and benzoylhydrazones, their DNA binding and antimicrobial activity," Journal of Inorganic Biochemistry, vol. 99, no. 3, pp. 876-882, 2005.

[32] A. C. Barve, S. Ghosh, A. A. Kumbhar, A. S. Kumbhar, and V. G. Puranik, "DNA-binding studies of mixed ligand cobalt(III) complexes," Transition Metal Chemistry, vol. 30, no. 3, pp. 312-316, 2005.

[33] N. Shahabadi, S. Kashanian, and M. Mahdavi, "DNA interaction studies of cobalt (II) mixed-ligand complexes containing dimethyl-1, 10-phenanthroline and dipyrido[3,2-a:2',3'c]phenazine: the role of methyl substitutions on the mode of binding," DNA and Cell Biology, vol. 30, no. 7, pp. 507-515, 2011.

[34] A. A. Vlcek, "Preparation of Co(dipy)2X2+ complexes (X$=$ chloride, bromide, iodide, nitrite) by controlled oxidative processes," Inorganic Chemistry, vol. 6, pp. 1425-1427, 1967.

[35] J. K. Barton, J. J. Dannenberg, and A. L. Raphael, "Tris(phenanthroline) $\mathrm{Ru}(\mathrm{II})$ : stereoselectivity in binding to DNA," Journal of the American Chemical Society, vol. 106, pp. 2172-2176, 1984.

[36] B. M. Zeglis, V. C. Pierre, and J. K. Barton, "Metallointercalators and metalloinsertors," Chemical Communications, no. 44, pp. 4565-4579, 2007.

[37] L. Jin and P. Yang, "Synthesis and DNA binding studies of cobalt (III) mixed-polypyridyl complex," Journal of Inorganic Biochemistry, vol. 68, no. 2, pp. 79-83, 1997.

[38] A. Dimitrakopoulou, C. Dendrinou-Samara, A. A. Pantazaki, M. Alexiou, E. Nordlander, and D. P. Kessissoglou, "Synthesis, structure and interactions with DNA of novel tetranuclear, [Mn4(II/II/II/IV)] mixed valence complexes," Journal of Inorganic Biochemistry, vol. 102, no. 4, pp. 618-628, 2008.

[39] J. G. Liu, Q. L. Zhang, X. F. Shi, and L. N. Ji, "Interaction of $\left[\mathrm{Ru}(\mathrm{dmp})_{2}(\mathrm{dppz})\right]^{2+}$ and $\left[\mathrm{Ru}(\mathrm{dmb})_{2}(\mathrm{dppz})\right]^{2+}$ with DNA: effects of the ancillary ligands on the DNA-binding behaviors," Inorganic Chemistry, vol. 40, no. 19, pp. 5045-5050, 2001.

[40] J. G. Liu, B. H. Ye, H. Li, L. N. Ji, R. H. Li, and J. Y. Zhou, "Synthesis, characterization and DNA-binding properties of novel dipyridophenazine complex of ruthenium (II): $\left[\mathrm{Ru}(\mathrm{IP})_{2}(\mathrm{DPPZ})\right]^{2+}$," Journal of Inorganic Biochemistry, vol. 73, pp. 117-122, 1999.

[41] R. M. Hartshorn and J. K. Barton, "Novel dipyridophenazine complexes of ruthenium(II): exploring luminescent reporters of DNA," Journal of the American Chemical Society, vol. 114, no. 15, pp. 5919-5925, 1992.

[42] P. B. Kandagal, S. M. T. Shaikh, D. H. Manjunatha, J. Seetharamappa, and B. S. Nagaralli, "Spectroscopic studies on the binding of bioactive phenothiazine compounds to human serum albumin," Journal of Photochemistry and Photobiology A, vol. 189, no. 1, pp. 121-127, 2007.

[43] M. Jiang, M. X. Xie, D. Zheng, Y. Liu, X. Y. Li, and X. Chen, "Spectroscopic studies on the interaction of cinnamic acid and its hydroxyl derivatives with human serum albumin," Journal of Molecular Structure, vol. 692, no. 1-3, pp. 71-80, 2004.

[44] N. Shahabadi and A. Fatahi, "Multispectroscopic DNA-binding studies of a tris-chelate nickel(II) complex containing 4,7diphenyl 1,10-phenanthroline ligands," Journal of Molecular Structure, vol. 970, no. 1-3, pp. 90-95, 2010.

[45] I. Haq, "Part II: the thermodynamics of drug-bipolymer interaction thermodynamics of drug-DNA interactions," Archives of Biochemistry and Biophysics, vol. 403, pp. 1-15, 2002.
[46] S. Ramakrishnan and M. Palaniandavar, "Interaction of rac$[\mathrm{Cu}$ (diimine) 3$] 2+$ and rac-[Zn(diimine) 3$] 2+$ complexes with CT DNA: effect of fluxional $\mathrm{Cu}(\mathrm{ii})$ geometry on DNA binding, ligand-promoted exciton coupling and prominent DNA cleavage," Dalton Transactions, no. 29, pp. 3866-3878, 2008.

[47] P. Uma Maheswari and M. Palaniandavar, "DNA binding and cleavage properties of certain tetrammine ruthenium(II) complexes of modified 1,10-phenanthrolines-effect of hydrogenbonding on DNA-binding affinity," Journal of Inorganic Biochemistry, vol. 98, no. 2, pp. 219-230, 2004.

[48] P. T. Selvi and M. Palaniandavar, "Spectral, viscometric and electrochemical studies on mixed ligand cobalt(III) complexes of certain diimine ligands bound to calf thymus DNA," Inorganica Chimica Acta, vol. 337, pp. 420-428, 2002.

[49] N. Shahabadi, S. Kashanian, and M. Mahdavi, "DNA interaction studies of cobalt (II) mixed-ligand complexes containing dimethyl-1, 10-phenanthroline and dipyrido[3,2-a:2',3' c] phenazine: The role of methyl substitutions on the mode of binding," DNA and Cell Biology, vol. 30, no. 7, pp. 507-515, 2011. 

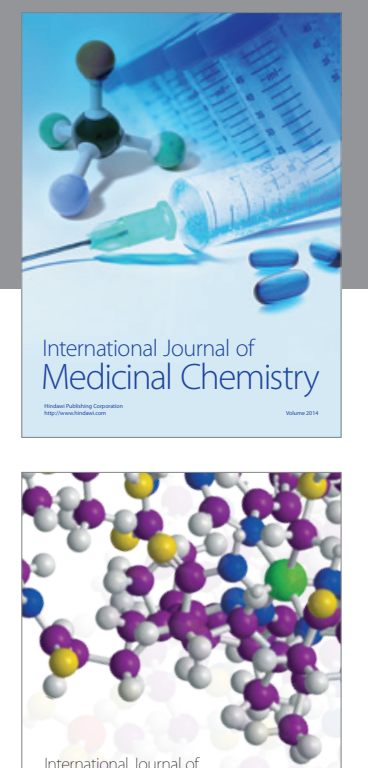

\section{Carbohydrate} Chemistry

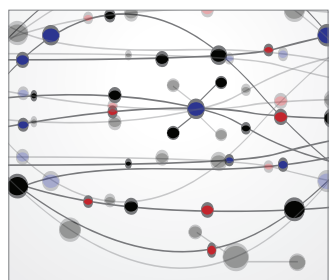

The Scientific World Journal
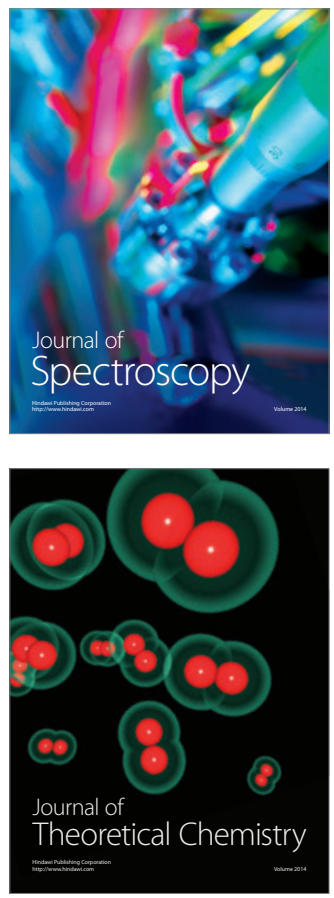
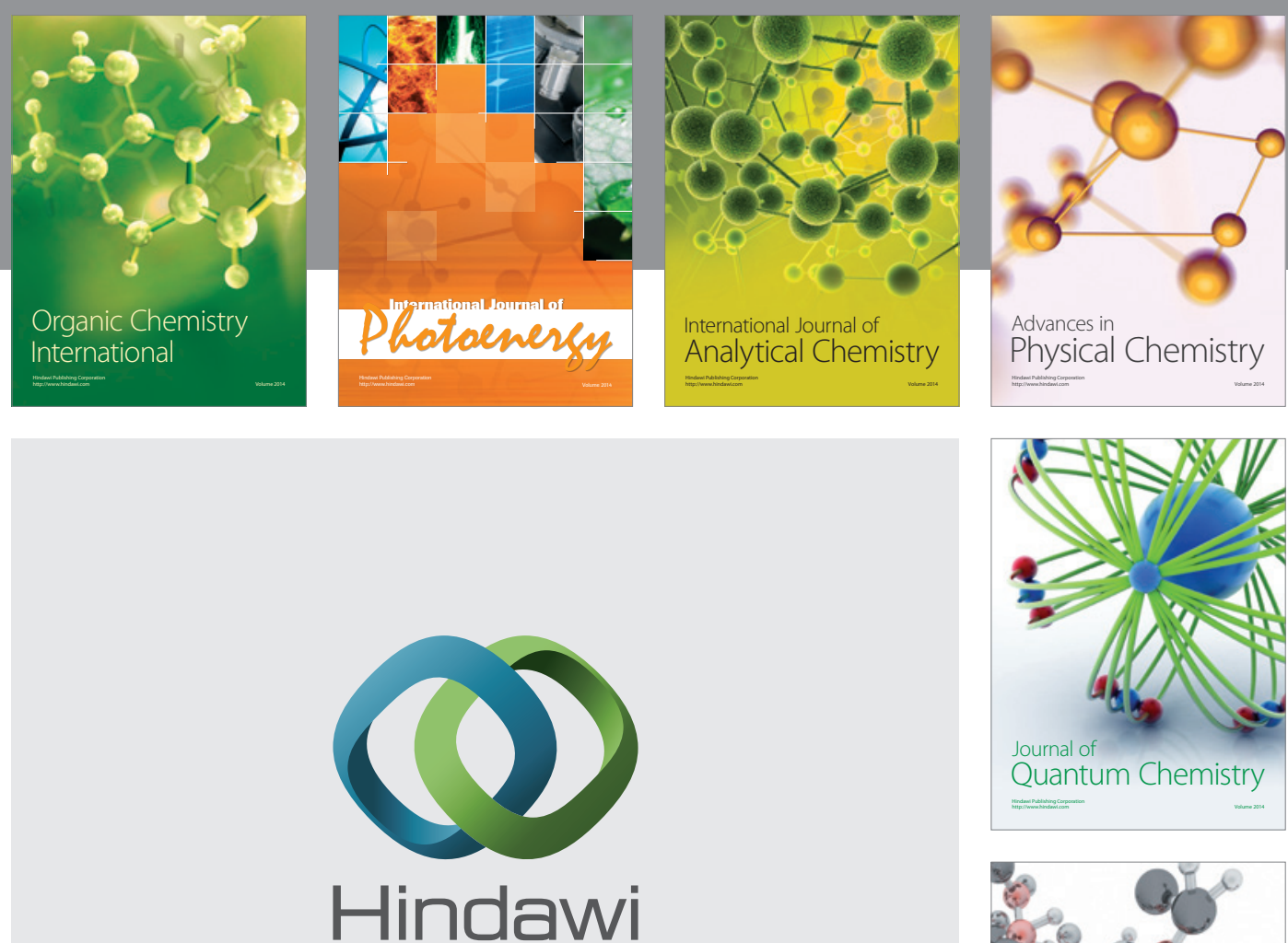

Submit your manuscripts at

http://www.hindawi.com

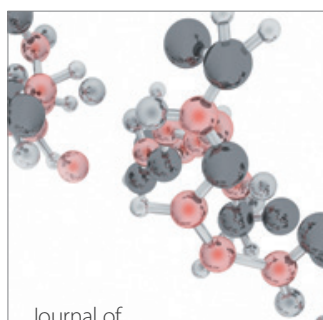

Analytical Methods

in Chemistry

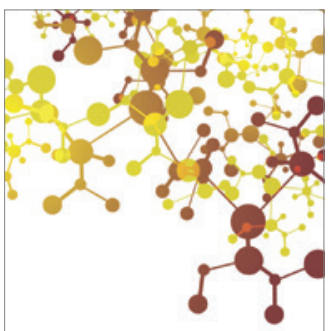

Journal of

Applied Chemistry

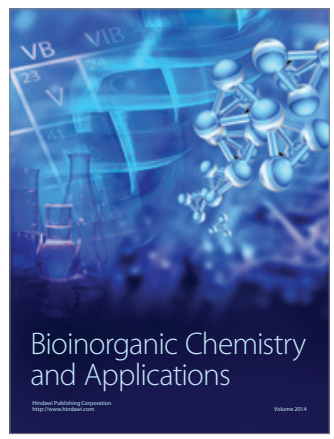

Inorganic Chemistry
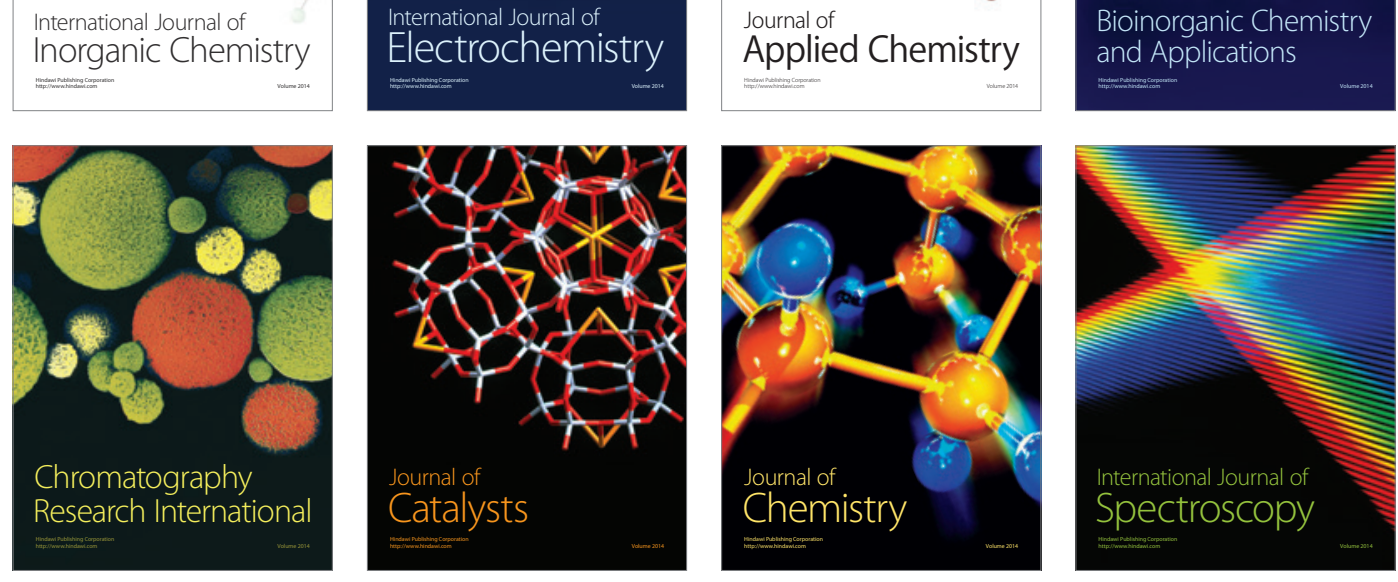